\title{
Early T Acute Lymphoblastic Leukemia
}

National Cancer Institute

\section{Source}

National Cancer Institute. Early T Acute Lymphoblastic Leukemia. NCI Thesaurus. Code C130043.

T acute lymphoblastic leukemia in which the blasts have unique immunophenotypic and genetic characteristics suggesting only limited early $\mathrm{T}$-cell differentiation. 